\title{
The Outcome of Induction Only Versus Induction and Maintenance With A Low Dose Intravesical BCG Therapy For High-Grade NMIBC
}

\author{
Md. Shamim Hossain ${ }^{1}$, Kartik Chandra Ghosh ${ }^{2}$, Akter Kamal Perveg ${ }^{3}$, Md. Enamul Hoque ${ }^{4}$ \\ ${ }^{1}$ Assistant Professor Of Urology, BSMMU, Dhaka, Bangladesh \\ ${ }^{2}$ Assistant Professor Of Renal Transplant Unit, Department Of Urology, BSMMU, Dhaka, \\ Bangladesh \\ ${ }^{3}$ Medical Officer, Department Of Urology, BSMMU, Dhaka, Bangladesh \\ ${ }^{4}$ Medical Officer, Department Of Urology, BSMMU, Dhaka, Bangladesh
}

*Corresponding Author: Md. Shamim Hossain, Assistant Professor Of Urology, BSMMU, Dhaka, Bangladesh.

\begin{abstract}
Background: According to standard guidelines, high-risk NMIBC (Non-Muscle Invasive Bladder Cancer) is treated by TUR (Transurethral resection) followed by intravesical immunotherapy $(B C G)$. Induction followed by maintenance is recommended for achieving maximum delay of tumor recurrence and progression.
\end{abstract}

Objective: This study aimed to find the outcome of induction only vs induction and maintenance, considering recurrence and progression of the disease.

Materials and Methods: This experimental study was conducted in BSMMU from June 2018 to December 2020 among the histologically proved high-risk NMIBC (Ta, Tl, and/ Tis) patients. Patients were allocated in two groups. In one arm BCG induction only and another arm induction and maintenance were implemented. Patients were followed up upto 2 years period. Disease recurrence and progression along with different local and systemic adverse effects were recorded add analyzed.

Results: Total 30 patients were allocated in 2 groups. 14 patients in induction only arm and 16 in induction and maintenance arm. Upto 24 months follow up-overall disease recurrence was $23.3 \%$ and disease progression was found in $10 \%$ of patients. $28.5 \%$ of the induction-only arm and $18.75 \%$ patients of induction and maintenance arm developed recurrence. Whereas $7.14 \%$ of the induction-only arm and $12.5 \%$ of other arm patients developed disease progression. Both were statically insignificant ( $p$ 0.198).

Conclusion: For high-risk NMIBC induction- only BCG therapy is not inferior to induction and maintenance therapy in terms of recurrence and progression, rather it has relatively fewer adverse effects.

Keywords: High-grade NMIBC, Induction and Maintenance BCG therapy, Induction only BCG therapy, Low dose Intravesical BCG therapy.

\section{INTRODUCTION}

Bladder cancer is a common genitourinary malignancy. The Incidence of bladder tumor is rising sharply throughout the world in both males and females due to various causes. According to standard guideline NMIBC (Non-Muscle Invasive Bladder Cancer), those are classified as high-risk group - treated by TUR(Transurethral resection) followed by intravesical immunotherapy(BCG). Since it was discovered by Morales et al in 1976 [13], Till now it is commonly practiced treatment protocol. According to many standard randomized trials, BCG (Bacillus CalmetteGuerin) reduces disease recurrence and delay disease progression than TUR alone. SWOG (Southwest Oncology Group) BCG protocol is the commonly used regimen for BCG therapy. According to SWOG- 21 doses of 
BCG were installed in the bladder in three years period. The BCG produces cumulative toxicity. So only $16 \%$ of patient of the SWOG trial could continue their treatment upto 3 years because of the toxicity[10]. The majority of current guidelines recommend maintenance BCG for 1-3 years.[5] Many other standard studies mentioned that maintenance is optional regarding efficacy and toxicity.[12] So BCG induction only therapy or induction and maintenance which is appropriate for high-risk NMIBC is still a controversial issue. Many studies are ongoing on this issue. This study aimed to find the outcome of induction only vs induction and maintenance, considering recurrence and progression of the disease.

\section{Materials and Methods}

This Experimental study was conducted in BSMMU from June 2018 to December 2020. After TURBT high-risk NMIBC patients were included in the registry. High-grade Ta, T1, and/ $\mathrm{T}_{\text {is }}$ were considered as high-risk group. Patients were allocated in two groups. In one arm BCG induction only and another arm induction and maintenance were implemented. Patients were distributed in two groups according to Even and Odd serial numbers in the registry. Those having concomitant other malignancies, poor performance status (ECOG/WHO-3,4), unwilling to participate in the study were excluded. For induction only arm BCG(40 milligrams dissolved in $40 \mathrm{ml}$ saline) was installed in the bladder -weekly for 6 weeks starting at least 14 days after TURBT(transurethral resection of bladder tumor). In another arm, induction and up to 3 years maintenance was planned according to SWOG guideline. For those patientsinstallation weekly for 6 weeks, then maintenance three weekly at $3,6,12,18,24,30$ and 36 months was scheduled.

In this study follow up performed upto 2 years after TURBT. Patient scheduled for Induction only therapy if developed recurrence were treated by another 6 weeks of BCG instillation. Patients were followed up at 3,6, 9 months, and at 1 year, thereafter 6 monthly with history, physical examination, cytology and cystoscopy. In this study complete response was defined as negative cytology and biopsy at 6 months follow up. During this period positive cytology or presence of tumor in biopsy specimen was considered as recurrence. On the other hand- muscle invention in the biopsy or metastasis was considered as disease progression. During this study period different local systemic adverse effects like-pain, frequency, haematuria, fever, malaise, were recorded and plotted accordingly. Data analysis performed using computer-based software.p vale <0.05 was considered as significant.

\section{Results}

In this study total 30 patients were followed up for 2 years period. Out of them- 14 patients were in induction only arm, whereas 16 patients were in another arm (Table-1). (Table 2) Induction only arm 4(28.50\%) patients developed recurrence, out of them- 1(7.14\%) patient had disease progression another three patients had a recurrence but no progression found. Recurrence was re-treated with weekly 6 dose of intravesical BCG. 1 patient who developed disease progression died due to bladder cancer another (1) patient of this arm died due to CVS-related complications. In the maintenance arm, three patients $(18.75 \%)$ developed recurrence among them two patients $(12.5 \%)$ developed disease progression one patient diet later due to bladder cancer. Another patient developed upper tract TCC(transitional cell carcinoma) presented with lung metastasis and diet from TCC. 1 patient diet due to CVSrelated complications. (Table 3) Four patients developed recurrence of the induction-only arm. All of them developed in the second year. (two at 18 months, another two at 24 months). In the maintenance arm, 3 patients developed recurrence- one at 9 months, one at 18 months, another at 24 months. Regarding disease progression, one patient of the induction arm developed progression at 24 months. In another arm, two patients developed disease progression at 9 months and at 18 months. Both recurrence and progression were statically insignificant comparing between the two groups. (Fig.-1) Recurrence-free survival up to 2 years in induction only arm was $71.4 \%$ and $81.25 \%$ in another arm. (Fig.-2) Progressionfree survival upto two years was $92.8 \%$ in induction only arm but $87.5 \%$ in the opposite arm. 
The Outcome of Induction Only Versus Induction and Maintenance With A Low Dose Intravesical BCG Therapy For High-Grade NMIBC

Table1. Comparison of age, sex, tumor types, size and category between two groups.

\begin{tabular}{|c|c|c|c|}
\hline & $\begin{array}{l}\text { Induction } \\
(\mathrm{n}=14)\end{array}$ & $\begin{array}{l}\text { Induction+ aintenance } \\
(\mathrm{n}=16)\end{array}$ & Total $(\mathrm{n}=30)$ \\
\hline $\begin{array}{l}\text { Age range year } \\
(\text { mean } \pm \mathrm{SD})\end{array}$ & $\begin{array}{l}28-85 \\
54.50 \pm 15.21\end{array}$ & $\begin{array}{l}30-86 \\
55.50 \pm 15.21\end{array}$ & \\
\hline $\begin{array}{l}\text { Gender, n (\%) } \\
\text { Male } \\
\text { Female }\end{array}$ & $\begin{array}{l}10(71.4 \%) \\
4(28.6 \%)\end{array}$ & $\begin{array}{l}11(68.75 \%) \\
5(31.25 \%)\end{array}$ & $\begin{array}{l}21(70.0 \%) \\
9(30.0 \%)\end{array}$ \\
\hline $\begin{array}{l}\text { Type of cancer, n (\%) } \\
\text { Primary } \\
\text { Secondary } \\
\text { Unknown }\end{array}$ & $\begin{array}{l}10(71.43 \%) \\
3(21.4 \%) \\
1(7.2 \%)\end{array}$ & $\begin{array}{l}10(62.5 \%) \\
6(37.5 \%) \\
0\end{array}$ & $\begin{array}{l}20(66.6 \%) \\
9(30.00 \%) \\
1(3.3 \%)\end{array}$ \\
\hline $\begin{array}{l}\text { Number of tumors, n (\%) } \\
\text { Single } \\
\text { Multiple }\end{array}$ & $\begin{array}{l}9(64.29 \%) \\
5(35.71 \%)\end{array}$ & $\begin{array}{l}11(68.75 \%) \\
5(31.25 \%)\end{array}$ & $\begin{array}{l}20(66.6 \%) \\
10(33.33 \%)\end{array}$ \\
\hline $\begin{array}{l}\text { Size, } \mathrm{n}(\%) \\
\leq 3 \mathrm{~cm} \\
>3 \mathrm{~cm}\end{array}$ & $\begin{array}{l}10(71.43 \%) \\
4(28.57 \%)\end{array}$ & $\begin{array}{l}12(75.00 \%) \\
4(25.00 \%)\end{array}$ & $\begin{array}{l}22(73.3 \%) \\
8(26.70 \%)\end{array}$ \\
\hline $\begin{array}{l}\text { T category, } \mathrm{n}(\%) \\
\text { TaG3 } \\
\text { T1G3 } \\
\text { Tis }\end{array}$ & $\begin{array}{l}10(71.43 \%) \\
3(21.4 \%) \\
1(7.2 \%)\end{array}$ & $\begin{array}{l}11(68.75 \%) \\
4(25.00 \%) \\
1(6.25 \%)\end{array}$ & $\begin{array}{l}21(70.00 \%) \\
7(23.30 \%) \\
2(6.70 \%)\end{array}$ \\
\hline
\end{tabular}

Table2. Comparison of outcome between two groups.

\begin{tabular}{|c|c|c|c|}
\hline & $\begin{array}{l}\text { Induction } \\
(\mathrm{n}=14)\end{array}$ & $\begin{array}{l}\text { Induction+ } \\
(\mathrm{n}=16)\end{array} \quad$ Maintenance & $\begin{array}{l}\text { Total } \\
(\mathrm{n}=30)\end{array}$ \\
\hline Recurrence & $4(28.5 \%)$ & $3(18.75 \%)$ & $7(23.3 \%)$ \\
\hline Progression $\geq T_{2}$ & $1(7.14 \%)$ & $2(12.5 \%)$ & $3(10 \%)$ \\
\hline Metastasis & 0 & $1(6.25 \%)$ & $1(3.3 \%)$ \\
\hline Alive patients & $12(85.7 \%)$ & $13(81.25 \%)$ & $25(83.3 \%)$ \\
\hline $\begin{array}{l}\text { Dead } \\
\text { (due to) } \\
\text { Bladder tumor } \\
\text { CVS disease } \\
\text { Other tumors } \\
\text { Other causes }\end{array}$ & $\begin{array}{l}2(14.25 \%) \\
1(7.14 \%) \\
1(7.14 \%) \\
0 \\
0\end{array}$ & $\begin{array}{l}3(18.75 \%) \\
1(6.25 \%) \\
1(6.25 \%) \\
1(6.25 \%) \\
0\end{array}$ & $\begin{array}{l}5(16.6 \%) \\
2(6.6 \%) \\
2(6.6 \%) \\
1(3.3 \%) \\
0\end{array}$ \\
\hline
\end{tabular}

Table3. Comparison of recurrence and progression between two groups.

\begin{tabular}{|l|l|l|l|l|l|}
\hline & Types of intervention & Total patients & $1^{\text {st }}$ year & $2^{\text {nd }}$ year & P-value \\
\hline Recurrence & Induction only & 4 & 0 & 4 & 0.198 \\
\cline { 2 - 6 } & Induction+ Maintenance & 3 & 1 & 2 & \\
\hline Progression & Induction only & 1 & 0 & 1 & \\
\cline { 2 - 6 } & Induction+ Maintenance & 2 & 1 & 1 & \\
\hline
\end{tabular}




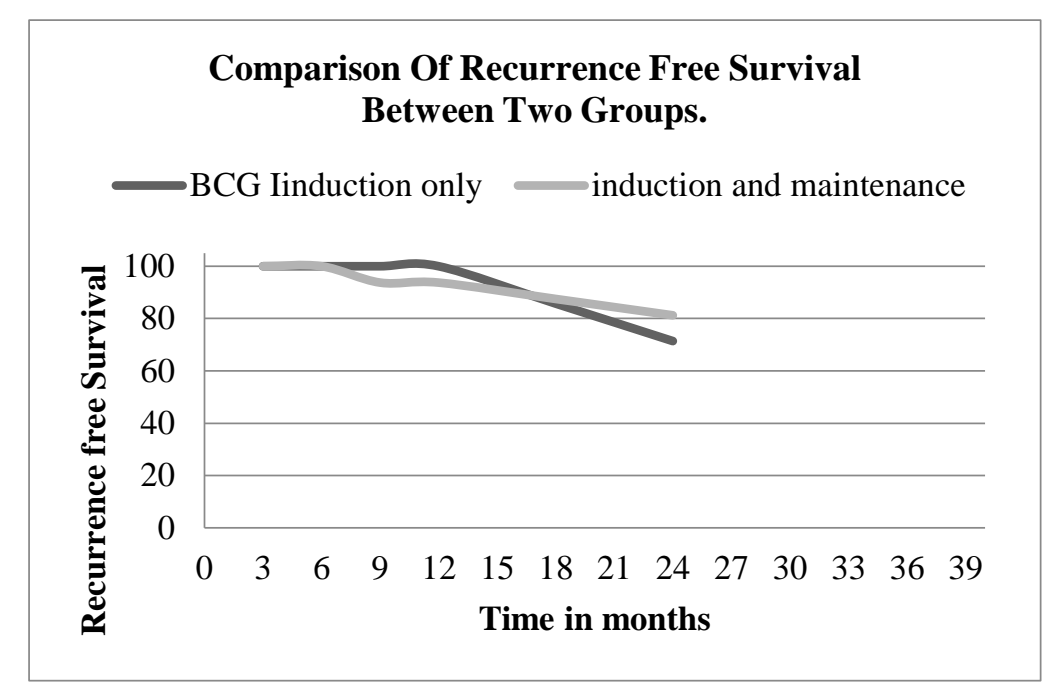

Fig1. Comparison of Recurrence free survival between two groups.

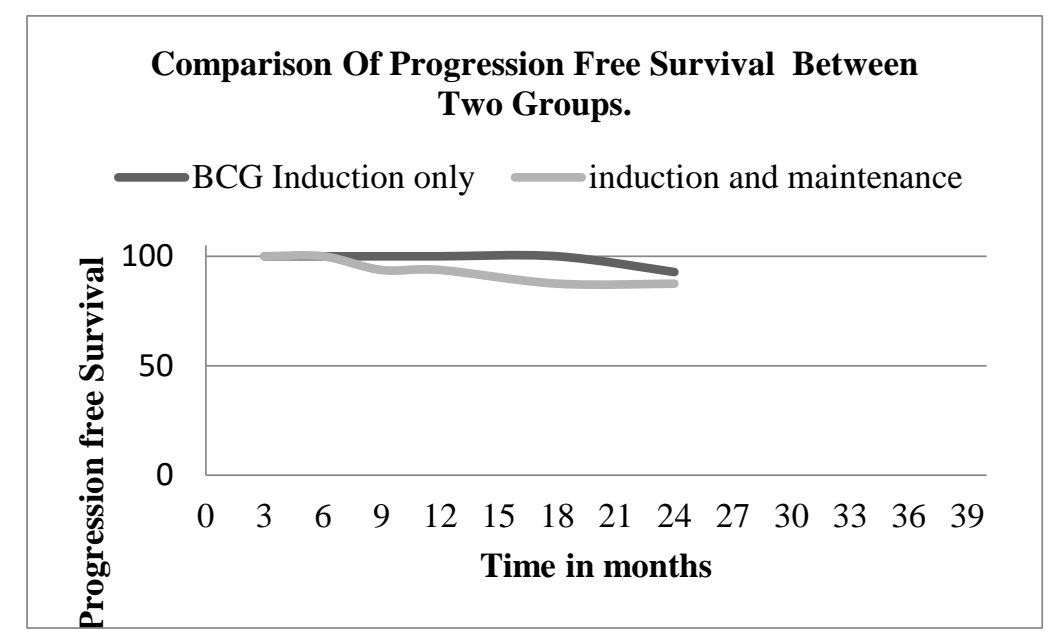

Fig2. Comparison of Progression-free survival between two groups.

Table4. Comparison of local and systemic adverse effects between two groups.

\begin{tabular}{|l|l|l|l|}
\hline & $\begin{array}{l}\text { Induction only } \\
\text { (total 7 patients 50.00\%) }\end{array}$ & $\begin{array}{l}\text { Induction+ Maintenance } \\
(\text { Total 10 patients 62.5\%) }\end{array}$ & P value \\
\hline Frequency & $7(50.00 \%)$ & $10(62.5 \%)$ & \multirow{2}{*}{0.334} \\
\hline Dysuria & $7(50.0 \%)$ & $11(68.75 \%)$ & \\
\hline Fever & $3(21.42 \%)$ & $7(43.75 \%)$ & \\
\hline Haematuria & $3(21.42 \%)$ & $5(31.25 \%)$ & \\
\hline Malaise & $1(7.14 \%)$ & $2(12.5 \%)$ & \\
\hline
\end{tabular}

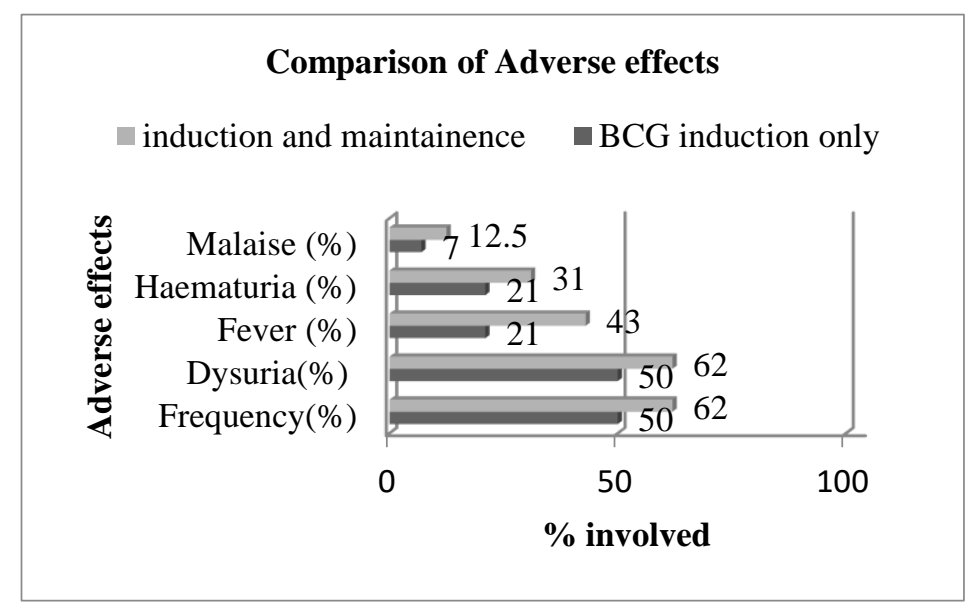

Fig3. Comparison of Adverse effects. 
Both groups of patients developed local and systemic adverse effects. The frequency was the most common adverse effect among the patients( $56.66 \%$ ). while the comparison of those effects between the two groups was statically insignificant in shows (Table-4 \& fig-3).

\section{DISCUSSION}

In this study 30 patients of high-risk NMIBC- 14 were in induction only arm and 16 were in induction and maintenance arm. Upto 24 months follow up ( $28.5 \%)$ of induction only and $(18.75 \%)$ patients of another arm developed recurrence. $7.14 \%$ of the induction-only arm and $12.5 \%$ of patients of the opposite arm developed disease progression. Total $16.6 \%$ of patients died in this 2 year follow-up period. $40 \%$ patient of them were in the $1^{\text {st }}$ group and $60 \%$ of patients were in the $2^{\text {nd }}$ group. The result of this study showed nearly similar recurrence and progression-free survival in comparison to some other standard randomized trials. 2-year recurrence-free survival rate was $72 \%$ on maintenance group and $10.4 \%$ of those patients had disease progression, which is similar to our data.[14] Standard review literature stated that 24 months recurrence-free survival rate varying between $54-89 \%$ by BCG therapy. [6] Another study result 2-year recurrence-free survival was $73 \%$ and progression-free survival was $11 \%$ in the induction only arm.[4] Local and systemic adverse effects by the standard dose of BCG induction ( $81 \mathrm{mg}$ suspended in $50 \mathrm{ml}$ saline) were relatively higher than this study.[10] In our study patient received nearly half of the standard dose BCG( $40 \mathrm{mg}$ dissolved in $40 \mathrm{ml}$ saline). this may be the cause of reduced adverse effects during this maintenance period without compromising the oncological outcome. It indicates BCG installation with a reduced dose can produce similar immunological efficacy. After all, results showed that the induction-only arm is not inferior to the induction and maintenance arm in terms of recurrence and progression upto 24 months follow-up period.

\section{LIMITATIONS}

It was a single-centered study where observation weres made on basis of 2 years follow-up period. Longer follow-up at least 5 years involving multiple centers, will be more effective regarding comments on decision making for adjuvant BCG therapy in high-risk NMIBC.

\section{CONClusion}

Maintenance BCG can reduce a few recurrences but the number is statically insignificant. Moreover maintenance therapy producers relatively more local and systemic adverse effects. In terms of recurrence and progression induction only is not inferior to induction and maintenance therapy rather it has relatively fewer adverse effects. So all the high-risk patient does not necessarily need maintenance therapy. However, in relapsing patients retreatment with induction therapy may be a logical salvage option.

\section{REFERENCES:}

[1]. Badalament RA, Herr HW, Wong GY, Gnecco C, Pinsky CM, Whitmore Jr WF, Fair WR, Oettgen HF. A prospective randomized trial of maintenance versus non maintenance intravesical bacillus CalmetteGuérin therapy of superficial bladder cancer. Journal of Clinical Oncology. 1987 Mar;5(3):441-9.

[2]. Böhle A, Gerdes J, Ulmer AJ, Hofstetter AG, Flad HD. Effects of local bacillus Calmette-Guerin therapy in patients with bladder carcinoma on immunocompetent cells of the bladder wall. The Journal of urology. $1990 \mathrm{Jul}$ 1;144(1):53-8.

[3]. Böhle A, Nowc CH, Ulmer AJ, Musehold J, Gerdes J, Hofstetter AG, Flad HD. Elevations of cytokines interleukin-1, interleukin-2 and tumor necrosis factor in the urine of patients after intravesical bacillus Calmette-Guerin immunotherapy. The Journal of urology. 1990 Jul 1;144(1):59-64.

[4]. Gontero P, Bohle A, Malmstrom PU, O’Donnell MA, Oderda M, Sylvester R, Witjes F. The role of bacillus CalmetteGuérin in the treatment of non-muscleinvasive bladder cancer. European urology. 2010 Mar 1;57(3):410-29.

[5]. Hall MC, Chang SS, Dalbagni G, Pruthi RS, Seigne JD, Skinner EC, Wolf JS, Schellhammer PF. Guideline for the management of nonmuscle invasive bladder cancer (stages Ta, T1, and Tis): 2007 update. The Journal of urology. 2007 Dec;178(6):2314-30.

[6]. Herr HW, Dalbagni G, Donat SM. Bacillus Calmette-Guérin without maintenance therapy for high- risk non-muscle-invasive 
bladder cancer. European urology. $2011 \mathrm{Jul}$ 1;60(1):32-6.

[7]. Herr HW, Laudone VP, Badalament RA, Oettgen HF, Sogani PC, Freedman BD, Melamed MR, Whitmore Jr WF. Bacillus Calmette-Guérin therapy alters the progression of superficial bladder cancer. Journal of Clinical Oncology. 1988 Sep;6(9):1450-5.

[8]. Herr HW, Schwalb DM, Zhang ZF, Sogani PC, Fair WR, Whitmore Jr WF, Oettgen HF. Intravesical bacillus Calmette-Guérin therapy prevents tumor progression and death from superficial bladder cancer: tenyear follow-up of a prospective randomized trial. Journal of Clinical Oncology. 1995 Jun;13(6):1404-8.

[9]. Herr HW. Is maintenance bacillus Calmette-Guérin really necessary? European urology. 2008 Jun 25;54(5):9713.

[10].Lamm Dl, Blumenstein Ba, Crissman Jd, Montie Je, Gottesman Je, Lowe Ba, Sarosdy Mf, Bohl Rd, Grossman Hb, Beck Tm, Leimert Jt. Maintenance bacillus CalmetteGuerin immunotherapy for recurrent TA, $\mathrm{T} 1$ and carcinoma in situ transitional cell carcinoma of the bladder: a randomized Southwest Oncology Group Study. The Journal of urology. 2000 Apr;163(4):11249.
[11].Martínez-Piñeiro L, Portillo JA, Fernández JM, Zabala JA, Cadierno I, Moyano JL, Solsona E, Unda M, Beardo P, RodríguezMolina J, Chantada V. Maintenance therapy with 3-monthly bacillus Calmette-Guérin for 3 years is not superior to standard induction therapy in high-risk non-muscleinvasive urothelial bladder carcinoma: final results of randomized CUETO Study 98013. European urology. 2015 Aug $1 ; 68(2): 256-62$.

[12]. Montie JE, Clark PE, Eisenberger MA, ElGalley R, Greenberg RE, Herr HW, Hudes GR, Kuban DA, Kuzel TM, Lange PH, Lele SM. Bladder cancer. Journal of the National Comprehensive Cancer Network. 2009 Jan $1 ; 7(1): 8-39$.

[13]. Morales A, Eidinger D, Bruce AW. Intracavitary Bacillus Calmette-Guerin in the treatment of superficial bladder tumors. The Journal of urology. 2002 Feb 1;167(2):891-4.

[14]. Oosterlinck W, Kirkali Z, Sylvester R, da Silva FC, Busch C, Algaba F, Collette S, Bono A. Sequential intravesical chemoimmunotherapy with mitomycin $\mathrm{C}$ and bacillus Calmette-Guerin and with bacillus Calmette-Guerin alone in patients with carcinoma in situ of the urinary bladder: results of an EORTC genitourinary group randomized phase 2 trial (30993). European urology. 2011 Mar $1 ; 59(3): 438-46$.

Citation: Md. Shamim Hossain, Kartik Chandra Ghosh, Akter Kamal Perveg, Md. Enamul Hoque, The Outcome of Induction Only Versus Induction and Maintenance With A Low Dose Intravesical Bcg Therapy For High-Grade Nmibc. ARC Journal of Urology. 2020; 6(1):15-20. DOI: https://doi.org/ 10.20431/2456060X.060103.

Copyright: () 2020 Authors. This is an open-access article distributed under the terms of the Creative Commons Attribution License, which permits unrestricted use, distribution, and reproduction in any medium, provided the original author and source are credited. 